\title{
YOUTH, HEALTH AND SOCIAL NETWORKS INSTAGRAM AS A RESEARCH TOOL FOR HEALTH COMMUNICATION
}

NATÀLIA CARCELLER-MAiCAS

Communication is key in the field of health, and the digital age did nothing but increase its importance. Today, the Internet and the new mass media have become basic communication tools, which in the case of young people, are sometimes essential. Most youngsters in the Western world have a latest generation mobile phone, which they use to communicate, access social networks and share their experiences instantly with their friends. Including communication tools such as Instagram in youth health fieldwork poses a number of challenges, but also has the potential for social health research, allowing us to reach young people and enrich research ethnographically.

Keywords: youth, emotional distress, methodological innovations, self-management of health, Instagram.

The use of digital devices is proliferating and affects us in increasingly varied and intense ways. The establishment of the Internet as a daily communication tool introduced changes in the means we use to communicate. The development and price reduction of digital technologies, together with the spread and simplification of the Internet, has allowed people to produce and share their own creations in a number of ways (Ardévol, Roig,

\& Gómez-Cruz, 2010). Within this new environment, we can find a wide range of new social media tools configured for the production, distribution and consumption of content, and they are at the fingertips of a large number of people. Even so, the acceptance and reception of such media by different social groups is diverse and depends on sociocultural factors.

Adolescents and young people are the age group that best and most quickly adapt to this technological advancement and incorporate it into their way of life (Purita, 2015; Rubio, 2010). Curiosity for this medium, together with the multiple communication and leisure possibilities it offers, perfectly fits their way of being and how they feel about the world, because communication and socialisation are their basic tools for understanding and sharing their world. Most youngsters in our society have a latest generation mobile phone, which they use to communicate, access social networks and share their experiences instantly with their friends. Regarding technological tools, mobile phones occupy a central role in their lives; they participate in their relationship management on an ongoing basis (Wood, Bokowski, \& Lis, 2015). It is used to communicate orally, visually, and in written form, thanks to different multimodal tools and applications that extend sociability and transform the social patterns of relationships, status and even visibility (Ito, Okade, \& Matsuba, 2005; McIntosh, 2010), allowing for new forms of intimacy.

We must not overlook the role that these types of devices, and their use or misuse, play in young people's lifestyles and in their place in the world (Best, Manktelow, \& Taylor, 2014). For this reason, in the last few years studies focused on these types of devices have proliferated. Works such as the one by Van House, Davis, Takhteyev, Ames and Finn (2004) have provided evidence for the emergence of new communication frames that are culturally recognised and continually reconfigured thanks, partly, to constant technological 
innovation and upgrades, which broadens the spectrum of communication forms. In fact, the inclusion of a digital camera in mobile phones has enabled new forms of communication and new ways to access information, intimately connected to the daily personal visions of the users. This favours the appearance of constant innovations.

\section{NEW APPROACHES TO HEALTH STUDIES}

We should be aware of the challenges posed by these innovations. As researchers, we have to adapt to the reality around us and take advantage of the possibilities these technologies offer for research. This is even more necessary and interesting when we deal with young people. The object of this study is the process of self-management of emotional distress in young people. This process includes all the representations and practices used by young people to understand, address and solve their emotional distress (anxiety and depression).

From the methodological point of view, the decision was taken to start identifying and analysing the self-management habits of young people by analysing what they do and say about themselves. The analysis of young people's self-service strategies and of the process known as the «patient's course» (Barragán, 2005) allow us to identify most of the ways we can assist them against the discomfort of a certain situation. This methodological approach allows researchers to observe the articulate and relational use young people make of professionals and lay knowledge.

Self-management of emotional distress is a constant structural process in continuous modification. There is a whole series of distressing situations experienced and self-managed in their day to day lives. In the face of such suffering they can either do nothing, or share it with someone, letting time fix it, which is another distress self-management practice (Menéndez, 2009). That is why it is interesting to address this phenomenon with methodological tools to allow for a constant flow of information. The use of tools that make profound and exceptional data collection possible, such as in-depth interviews and focus or discussion groups, allow researchers to extract large amounts of information and discover new analytical categories step by step, as well as to create a solid connection with its informants. But the use of a tool like Instagram provides information that could not be obtained with traditional static data collection systems.

Instagram is an interactive tool used for the constant exchange of information, so it allows us
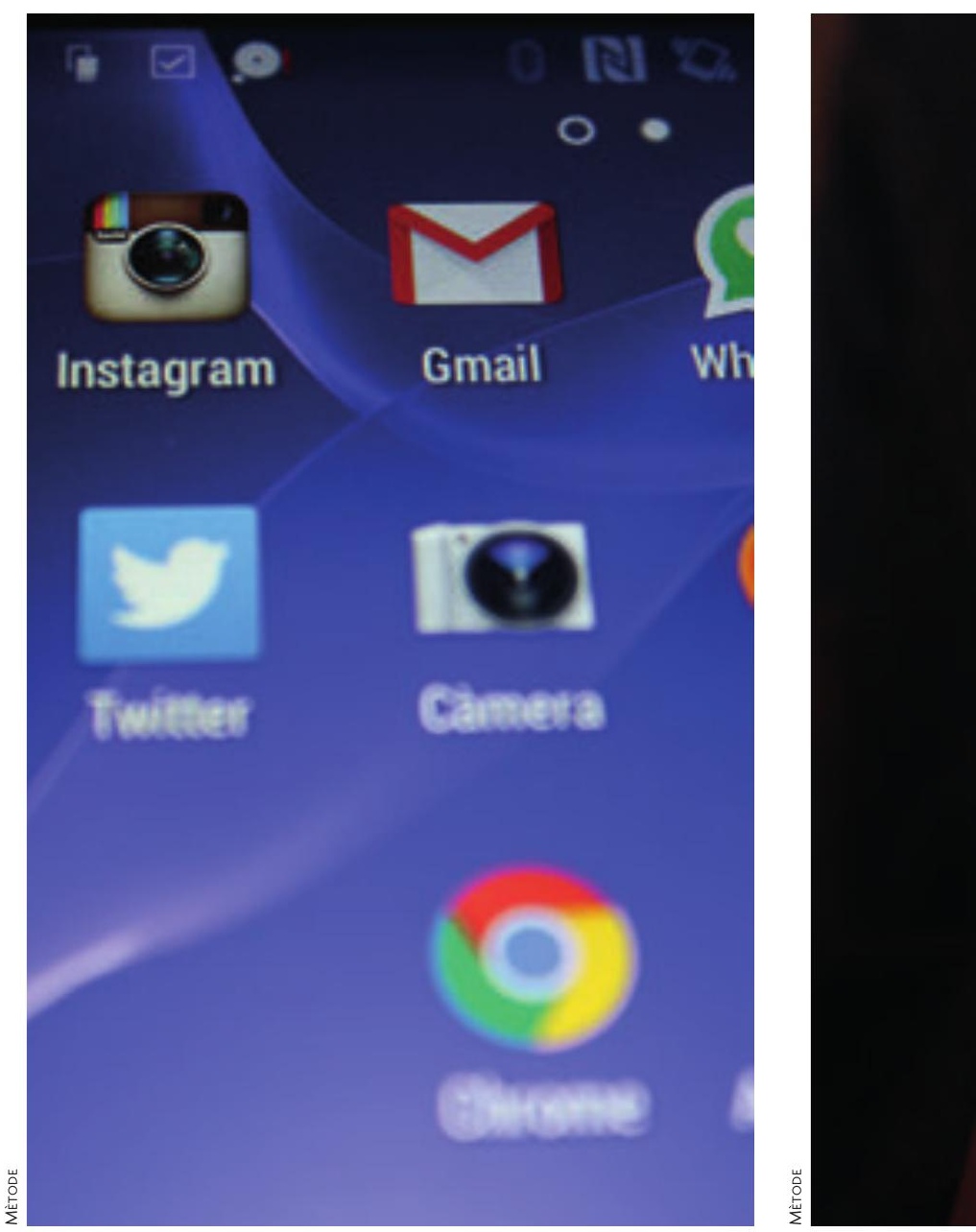

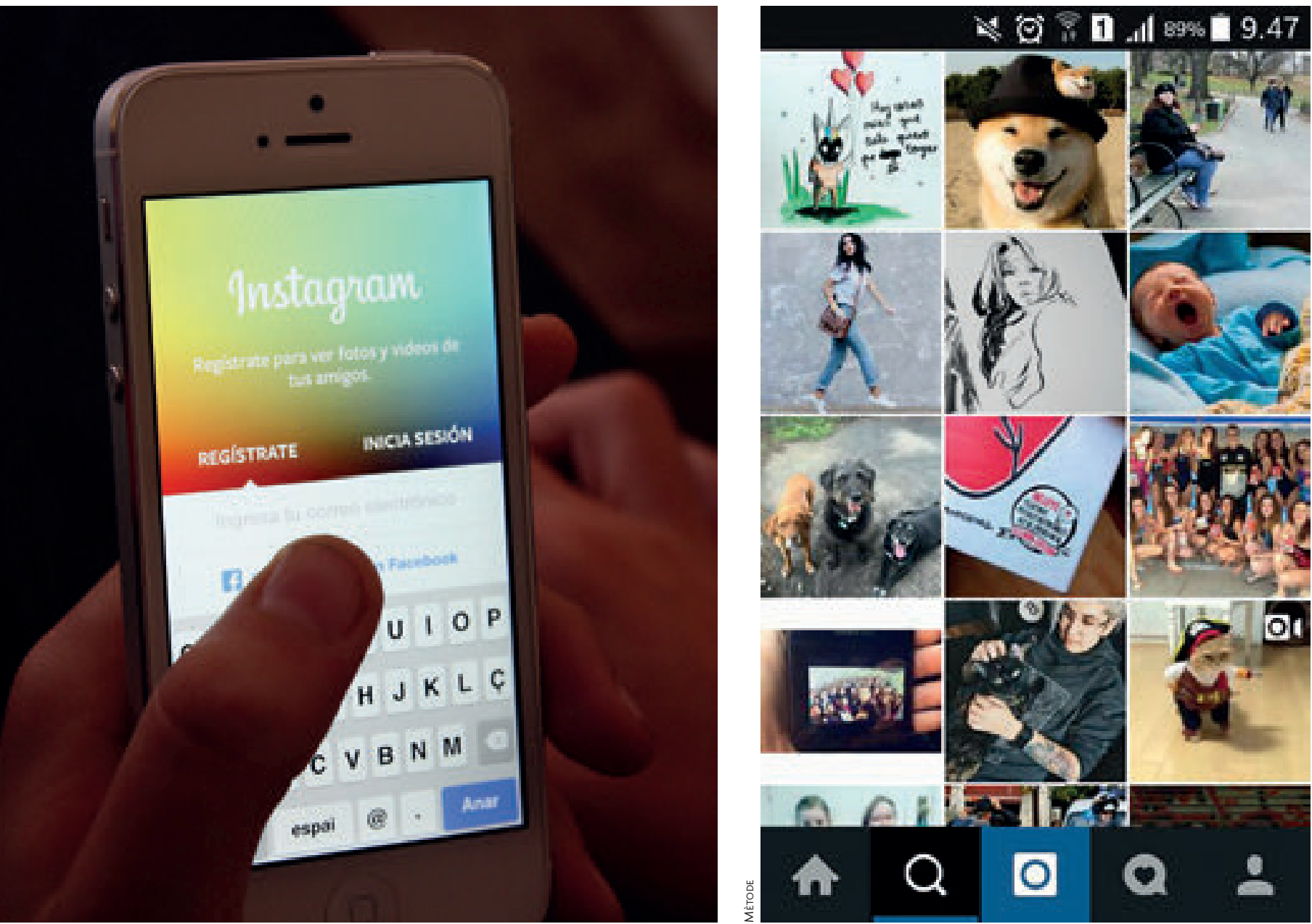

Instagram is a free application for iPhones and Android. It allows the user to take pictures and short videos (3-15 seconds), modify them and share them on social networks such as Facebook, Twitter, Flickr or on Instagram itself. The application became available in October 2010 and currently has more than 400 million users around the world.

to see and instantly analyse communication flows, as well as the changes and variation in the mood of its informants. This peculiarity makes it possible to collect data on the emotional self-management strategies used by young individuals and how they change over time. When dealing with an object matter such as this, the role of communication is key, because the distress narratives and discourses created and reconfigured by the young individual during their experience provides information which is essential for reaching a better understanding of the phenomenon. But the narratives, as observed with the emergence of applications such as Instagram, are not only oral, but also written and visual; thus, it is interesting to use methodological tools like this one to advance research by using the richness of the communication channels and modes now used by young people.
Regarding the online/offline debate, we support the critical contributions of authors such as Carter (2005) and consider that online and offline relationships overlap and are integral parts of the same reality. This was shown during participant observation in an adolescent working group in Catalonia. It was observed that, in the aforementioned context, mobile phones occupied a central space in young people's lives, and the different ways that young people relate to each other in the physical and virtual world became evident. The researchers saw that the adolescents created different subgroups via Instagram which contained relationships and dialogues that were different from the ones that produced at the same time in the physical world. The adolescents shared more intimate information online than they did offline, because of the discretion offered by the former environment. 
This led to the idea of introducing this data collection tool into research on the self-management process for emotional distress.

\section{INSTAGRAM AS A FIELDWORK TOOL}

Instagram is a free application for iPhone and Android. It allows the user to take pictures, modify them and share them on social networks such as Facebook, Twitter, Flickr or Instagram itself. The application became available in October 2010 and currently has more than 400 million users around the world (Instagram, 2015). Instagram is the social network with the sharpest growth among Spanish users (Purita, 2015), and the second most popular social network among young users, second only to Youtube (Forbes, 2015). It is a versatile application, which can capture everyday moments and add comments to the pictures, and offers a new range of possibilities to get closer to the investigated reality. This interactive application is very widely used by adolescents, and it is free, which makes it easier for field workers to include it as a complementary tool.

We identified a deficiency in our research: distress narratives by its informants could not be complemented with visual material to show how young people think, feel and live their emotional distress, or what self-management strategies they use. We liked Cárdenas's idea of using «pictures as tools, as a source, as a process (for representation, reflection, research, systematisation) with the possibility for visual documents to be open, to be triggers, to be recyclable» (Cárdenas, 2006, p. 6), and of working with pictures, using participatory methodology so young people could be a proactive part of the research process. Pictures permit the creation of a world representation based on imitating reality, because it implicitly organises discourse around themselves, turning reality into narration. The use of pictures provides «visual documentation for cultural registries, building a range of qualitative data» (Pereira da Silva $\&$ Pires, 2008). Therefore, if the goal of this research was to deal with self-management of emotional distress in young people using their own narratives, discarding their visual narratives implied that information was being lost. The use of Instagram as a data collection tool is not alien or intrusive to young

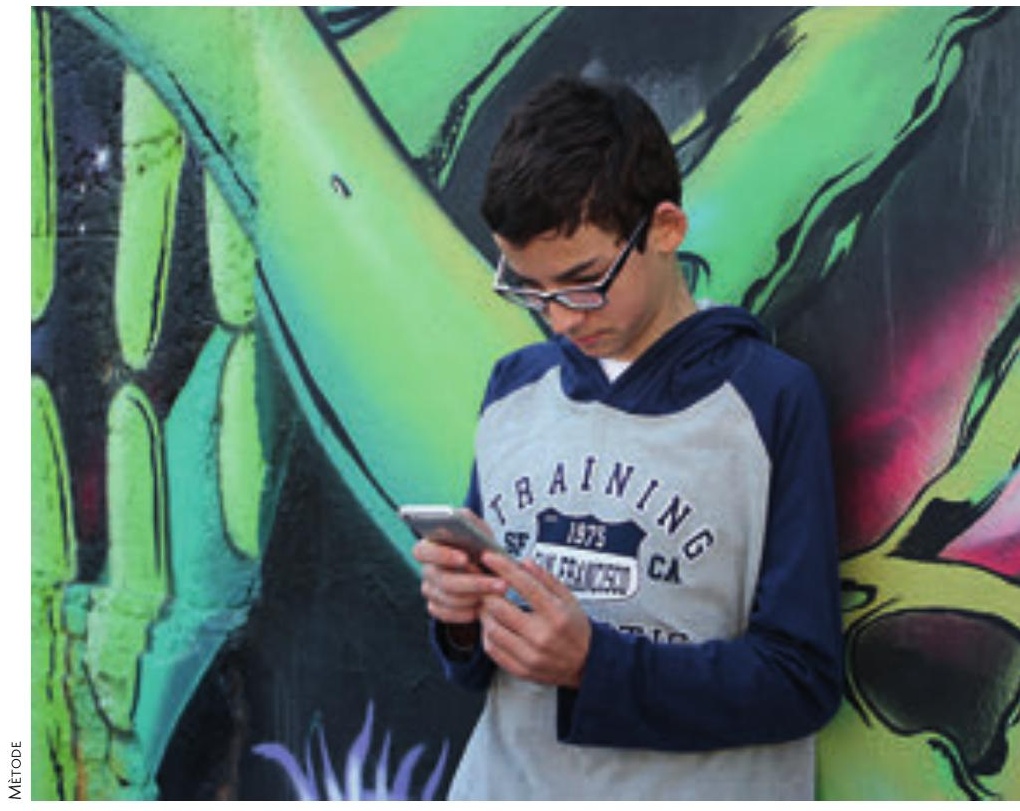

Most youngsters in our society have a latest generation mobile phone, which they use to communicate, access social networks and share their experiences instantly with their friends.

people because they often use it to share visual content with a strong emotional charge. This tool is being already being used in social and communicative situations, which greatly facilitates its introduction as a data collection tool.

Pictures are part of the process of configuration as individuals, of the emotional world, and «part of our

internal reality, part of our subjectivity» (Ardévol $\&$ Muntañola, 2004). If the pictures are created by the young people themselves, they will not only reflect their world but also the reality of their lives, what they think and what they feel they are. The inclusion of visual communication with photographs in this research is interesting because it broadens the channels and modes of communication and allows the users to express and share their experiences and perceptions, and discourses regarding their emotional health in ways that feel close and familiar.

\section{ADVANTAGES OF INCLUDING INSTAGRAM IN CLASSICAL RESEARCH METHODOLOGY}

In the current media context, old and new media constantly coexist, and new intersections appear 


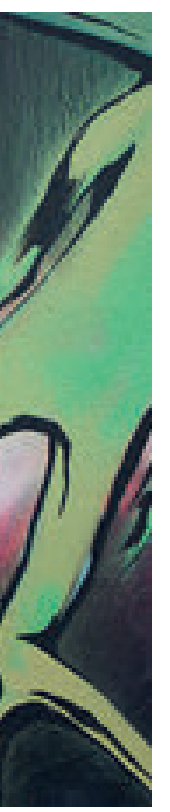

between them and social agents. Articulating classical methodologies together with new technological contributions nurtures research with the advantages of both. Information and Communication Technologies (ICT) modify reality. As researchers, we cannot remain blind to these changes. This new circumstance poses a new challenge for researchers: to incorporate new approaches to the professional observation of social reality (Pichardo Galán,

2008).

With the arrival of cameras on mobile phones and applications such as Instagram, the possibility of creating self-representation material increased; incorporating the Internet and related devices provides an exceptional framework for approaching these perspectives. Self-representation can help to explore reflexive and autobiographical genres, and can be an entry point to informants' subjectivity. It can help to create richer content in terms of subjective meaning (as well as shared meanings in the juxtaposed inter-subjective worlds). The use of such techniques also fosters the participation of informants in the research process. It allows young people to stop being passive subjects, enabling them to be empowered subjects who build their own selfrepresentation, which is one of the true potentials of the use of communication tools (Cárdenas, 2006). Horizontal communication is an advantage linked to the participatory process. Making it possible for informants to play an active role in the research process helps to break the interviewer/ interviewee hierarchy so they can work on the same cooperative level, as both ethnographer and informant

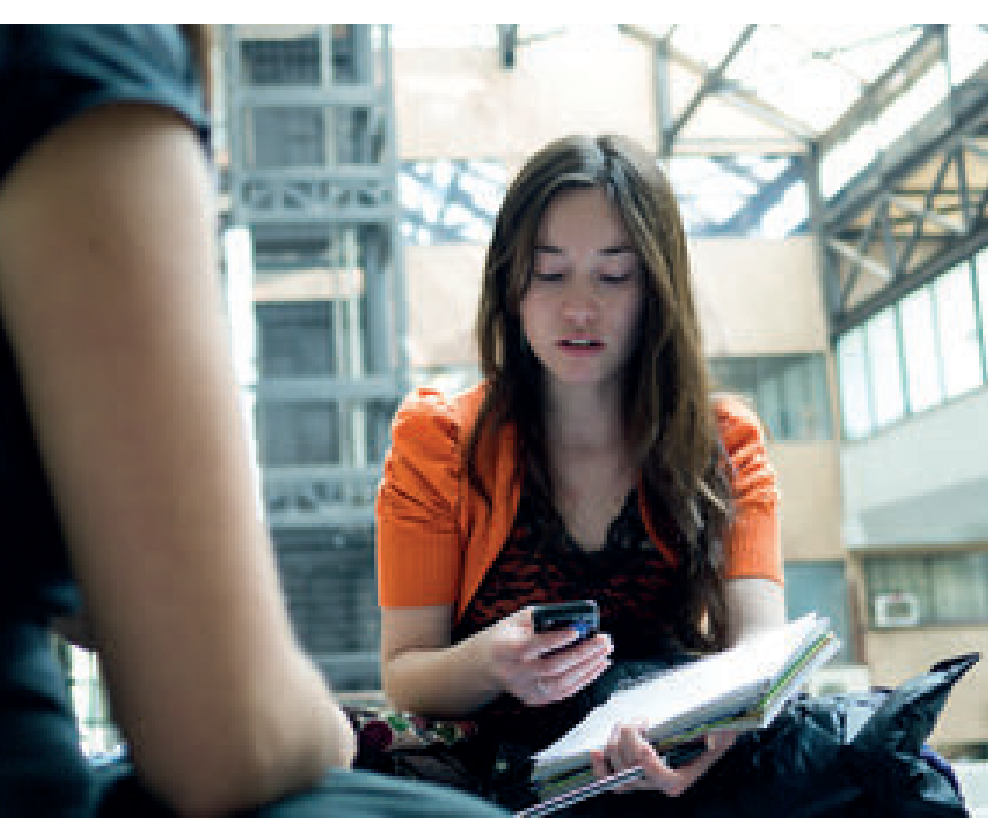

The use of Instagram as a data collection tool is not alien or intrusive to young people, because they often use it to share visual content with a strong emotional charge. This tool is already being used in social and communicative situations, which greatly facilitates its introduction as a data collection tool.

\footnotetext{
"ADOLESCENTS SHARED MORE INTIMATE INFORMATION ONLINE THAN THEY DID OFFLINE, BECAUSE OF THE DISCRETION OFFERED BY THE FORMER ENVIRONMENT»
}

communicate horizontally. Horizontality allows the creation of better, more reliable ties, so the informant feels more comfortable, esteemed and motivated as an integral and active part of the research.

The continuous flow of information and interactivity are other important advantages. Thanks to applications such as Instagram, the communication thread between the researcher and those being researched is strong and is relevant. The amount of information that can be collected increases, communication becomes richer, and the researcher can get closer to the informants.

But another of Instagram's major advantages turns it into a prominent tool for working with young people regarding health issues: it overcomes time and space limitations. Being able to create long-lasting virtual focus groups with this tool presents a potential to boost ethnographic field work and helps researchers and informants to avoid continued and expensive journeys. Mobile phones are one of the «immutable mobiles» (Latour, 1992) that can be moved while their information remains, so they are useful for longdistance actions. It is a buffer, «accentuating and permitting the coexistence of different and distant spaces and groups» (Lasén Díaz, 2006, p. 158). Young people are more accustomed to audio-visual media than purely written text or verbal and abstract material (Lisón Arcal, 1999), and are experts in the use of both the mobile phone camera and the Instagram software. Thus, having informants who are experts in the data collection tool, a good amount of quality material 


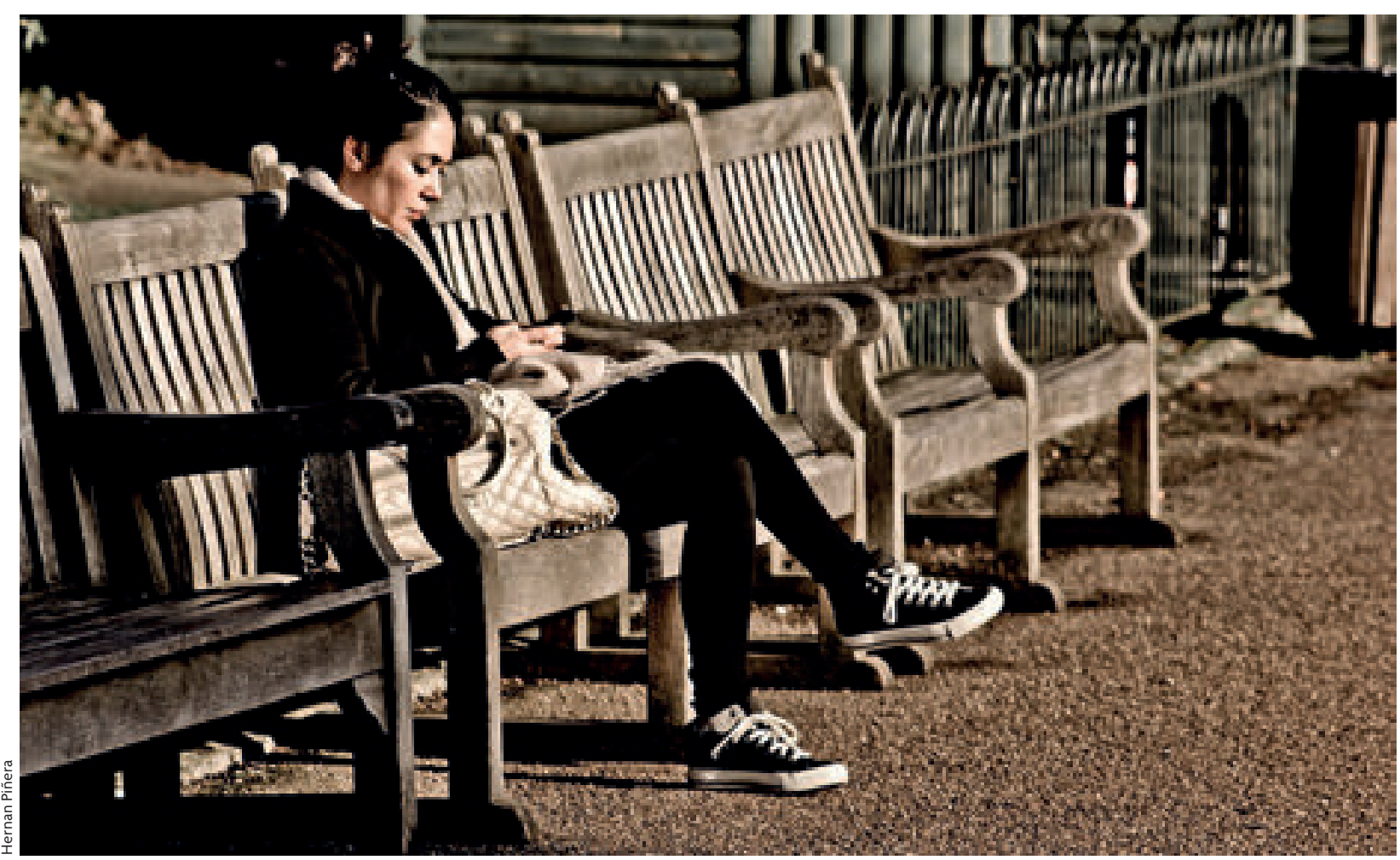

Young people experience emotionally distressing situations at different points in their lives, both when they are in a group and when they are alone at home. The use of Instagram allows young people to immediately share these moments of anxiety with the researcher and the group of informants.

can be obtained without physically being in the field. This advantage is even more important in the case of health studies, because it allows the researchers to collect data about emotional distress that cannot be obtained in any other way. Young people experience emotionally distressing situations at different points in their lives, both when they are in a group and when they are alone at home. The use of Instagram allows young people to share these moments of anxiety with the researcher and the group of informants immediately, and helps them to share and express how they experience distress when it happens, not only in retrospect. The perception of emotional distress and the consequent explanatory discourse that accompanies it can mutate, be re-thought and re-built over time and with experience. It is for this reason that having both an in situ distress narrative and another one $a$ posteriori is so enriching for research. It makes it possible to reach a better understanding of the process of emotional distress lived by the young individual, thanks to comparative analysis.

\section{CONCLUSIONS}

Technology's presence in our lives continues to increase, and it presents a wide spectrum of possibilities that scientists need to learn how to use. Although the digital world is not our subject of study, we can still take advantage of it to enrich our anthropological work, incorporating the use of new technologies as a methodological strategy and as a tool for improving our communication with informants and the production of evidence-based research material.

The proposal of this article emphasises the importance of communication in the research process for health studies, and promotes the integration and articulation of classical tools and methodologies, as well as new technologies and media as a means to that end. The Internet has become a co-participant in the process of gaining knowledge and constructing relationships, which should be taken into account, especially when working with young people. The changes this involves 
introspection in our professional work, and it invites researchers to explore the possibilities of combining «classical» and «new» methodologies.

These methodological tools offer a number of advantages: they make it easier to incorporate visual anthropology into our research, to increase the range of expression and communication means and their richness, variety and creativity, and to overcome the limitations of basic thought categories such as time and space, allowing for «long-lasting virtual discussion groups» that can provide information of a quality and quantity that was not possible using classical methodologies.

The most prominent potential of using Instagram for youth health research is related to the participation and collaboration of the study's informants; to the promotion of horizontality in the researcher/researchee relationship; the increase and enrichment of the information flow; the possibility to maintaining continued and permanent interaction among informants and between the informant and the ethnographer; and of overcoming the spatial limitation of fieldwork.

The more diverse, broad and enriching our communicative relationship is with our young informants, the better quality and higher quantity of information they will share with us, so we will have more data for our research. When we talk about youth health, and specifically about the selfmanagement of emotional distress, we find many problems with the currently available information. Creating a strong connection, with dialogue based on horizontality and reciprocity between the researcher and the researchee, is essential to fill these holes. At this point, using a new-generation dialogic communication tool like Instagram can help. We must know our informants, get closer to their world and adapt to their usual means of communication in order to make it easier for them to express their experiences and emotional anxieties. As researchers, we must not limit our creativity and analysis potential, so we need to reflect upon these questions in future ethnographic studies. (†)

\section{REFERENCES}

Ardévol, E., \& Muntañola, N. (Coords.). (2004). Representación y cultura audiovisual en la sociedad contemporánea. Barcelona: Editorial UOC. Ardévol, E., Roig, A., \& Gómez-Cruz, E. (2010). Pràctiques creatives i participació en els nous mèdia. Quaderns del CAC, 34, 27-36.
Barragán, A. (2005). La interrelación de los distintos modelos médicos en la atención del dolor crónico en un grupo de pacientes con neuralgia posherpética. Cuicuilco, 12(33), 61-78.

Best, P., Manktelow, R., \& Taylor, B. (2014). Online communication, social media and adolescent wellbeing: A systematic narrative review. Children and Youth Services Review, 41,27-36. doi: 10.1016/j.childyouth.2014.03.001

Cárdenas, C. (2006). Imágenes de trabajo. Reflexiones hacia una antropología visual aplicada. El caso del proyecto internacional juvenil Barrios del Mundo y su enfoque comunicativo. Revista Chilena de Antropología Visual, 8, 24-46.

Carter, D. (2005). Living in virtual communities: An ethnography of human relationships in cyberspace. Information, Communication \& Society, 8 , 148-167. doi: 10.1080/13691180500146235

Forbes. (2015, 14 May). Las 5 redes sociales con más crecimiento en 2015. Forbes. Retrieved from http://www.forbes.com.mx/las-5-redes-socialescon-mas-crecimiento-en-2015

Instagram. (2015, 22 September). Celebrating a community of 400 milion. Instagram. Retrieved from blog.instagram.com/post/129662501137/150922400million

Ito, M., Okade, D., \& Matsuba, M. (2005). Personal, portable, pedestrian: Mobile phones in Japanese life. Cambridge, MA: MIT Press.

Lasén Díaz, A. (2006). Lo social como movilidad: usos y presencia del teléfono móvil. Política y Sociedad, 43(2), 153-167. Latour, B. (1992). Where are the missing masses? The sociology of a few mundane artifacts. In W. E. Bijker, \& J. Law (Eds.), Shaping technology/building society: Studies in sociotechnical change (pp. 225258). Cambridge, MA: MIT Press.

Lisón Arcal, J. C. (1999). Una propuesta para iniciarse en la antropología visual. Revista de Antropología Social, 1, 5-35.

McIntosh, J. (2010). Mobile phones and Mipoho's prophecy: The powers and dangers of flying language. American Ethnologist, 37(2), 337-353. doi: 10.1111/j.15481425.2010.01259.x

Menéndez, E. (2009). De sujetos, saberes y estructuras. Introducción al enfoque relacional en el estudio de la salud colectiva. Buenos Aires: Lugar Editorial.

Pereira da Silva, S. L., \& Pires, M. D. C. F. (2008). Identidades visuales: Vídeo y fotografía en las formas de representación de la identidad de Rio de Janeiro. In E. Ardévol, A. Estalella \& D. Domínguez (Coords.), La mediación tecnológica en la práctica etnográfica (pp. 39-147). Sant Sebastià: Ankulegi Antropologia Elkartea.

Pichardo Galán, J. I. (2008). Etnografía y nuevas tecnologías: Reflexiones desde el terreno. In E. Ardévol, A. Estalella, \& D. Domínguez (Coords.) La mediación tecnológica en la práctica etnogràfica (pp. 131-149). San Sebastián: Ankulegi Antropologia Elkartea.

Purita, G. (2015). Análisis de las tendencias de uso y participación en las redes sociales a nivel mundial en España. Barcelona: Online Business School. Retrieved from http://recursos.anuncios.com/files/681/25.pdf Rubio, A. (2010). Jóvenes en red, generación digital y cambio social. In: Ciutadania Jove 2.0. XXVIII Jornades de Polítiques Locals de Joventut. Barcelona. Retrieved from http://www.diba.cat/documents/95670/96986/ joventut-fitxers-2010rubio-pdf.pdf

Van House, N., Davis, M., Takhteyev, Y., Ames, M., \& Finn, M. (2004). The social uses of personal photography: Methods for projecting future imaging applications. Berkeley School of Information. Retrieved from http:// people.ischool.berkeley.edu/ vanhouse/van\%20house_et_al_2004b\%20.pdf Wood, M. A., Bukowski, W. M., \& Lis, E. (2015). The digital self: How social media serves as a setting that shapes youth's emotional experiences. Adolescent Research Review. doi: 10.1007/s40894-015-0014-8

Natàlia Carceller-Maicas. Medical anthropologist and member of the Medical Anthropology Research Centre at the Rovira i Virgili University (Tarragona, Spain), where she is currently performing research for her $\mathrm{PhD}$. She is an expert on youth, emotions and drugs and is the author of several scientific and technical texts on youth, adolescence, emotions, drugs, mental health and participatory research-action. 